\title{
PENELITIAN
}

\section{STUDI FENOMENOLOGI TENTANG PENGALAMAN WANITA DI DAERAH PEDESAAN DALAM MENJALANI MASA KEHAMILAN PERTAMA}

\author{
Yati Afiyanti *
}

\begin{abstract}
Abstrak
Kehamilan seringkali dianggap sebagai periode transisi dalam kehidupan seorang wanita. Suatu studi kualitatif secara hermeneutik fenomenologi telah dilakukan untuk mengeksplorasi berbagai pengalaman wanita di daerah pedesaan dengan kehamilan pertamanya termasuk pengalaman mereka menerima pelayanan kesehatan dari para praktisi kesehatan

Data studi ini diperoleh dari 9 ibu muda, dikumpulkan melalui wawancara formal tidak berstruktur yang mendalam sebanyak dua kali di rumah partisipan masing-masing. Wawancara direkam kemudian dibuat dalam bentuk transkrip wawancara. Hasil penelitian mengungkapkan berbagai pengalaman wanita yang bervariasi. Kebanyakan ibu muda dalam studi ini mengalami kesulitan mengatasi berbagai ketidaknyamanan fisik dan psikologis akibat kehamilan dan mengalami kecemasan menghadapi proses kelahiran bayi mereka. Mereka membutuhkan dukungan dan bantuan, baik dari para praktisi kesehatan maupun anggota keluarga. Dengan hasil studi ini, diharapkan para praktisi kesehatan akan lebih memahami harapan-harapan seorang ibu hamil untuk dapat menjalani masa kehamilannya dengan sehat dan sejahtera.
\end{abstract}

Kata kunci: kehamilan pertama; pengalaman dan persepsi wanita hamil

\begin{abstract}
Pregnancy often assumed as transition period in the woman's life. A Qualitative studi, using fenomenology hermeunetic was carried out to explore women's experiences in rural area of their first pregnancy, included their experiences received from the health care provider.

Data were obtained from 9 women whose unstructured formal interviews were tape-recorded dan transcribed. Interviews were conducted in the women's homes on two occasions during pregnancy. The findings reported the women's experiences were varied and diverse. Most had difficulty coping with the physical and emotional symptoms of pregnancy. Loss of control caused anxiety toward with their childbirth The need for support emerged as important from their family and the health care providers. The findings of this study will provide the health care providers deeper understanding about the expectances of new expectant mothers with their first pregnancy, healthy dan wellness.
\end{abstract}

Key words: experiences and perception of expectant mother; first pregnancy

\section{LATAR BELAKANG}

Peristiwa kehamilan dianggap sebagai suatu periode transisi dalam kehidupan seorang wanita, yang menyebabkan dirinya mengalami perubahan peran dan status menjadi seorang ibu. Barclay, dkk.(1997) menyatakan peristiwa ini memiliki perbedaan nyata sebagai suatu peristiwa transformatif budaya, sosial, dan fisik yang pada akhirnya memunculkan berbagai definisi kehamilan dipandang dari aspek budaya dan aspek biologis.

Berbagai perubahan baik fisik maupun psikososial dan sejumlah stressor dapat dialami para wanita selama mereka menjalani masa kehamilan (Barclay dkk., 1997; Mercer, 1986; Rubin, 1984). Sebagian besar wanita hamil mungkin mengalami stress yang berat selama masa kehamilannya. Hal ini banyak terjadi terutama pada wanita yang baru pertama kali menjalani masa kehamilan karena belum memiliki pengalaman sebelumnya (Ball, 1994; Richardson, 1993).

Sejumlah penelitian telah melaporkan tentang pengalaman dan persepsi para wanita Eropa dan Amerika Utara (Stoppar, 1996; Adelaide, 1997; Eisenberg dkk, 1997; Fallows, 1997; LlewellynJones, 1998) dengan kehamilan mereka, sementara 
masih sangat sedikit informasi tentang pengalaman wanita Indonesia menceritakan tentang kehamilannya. Selain itu, belum banyak informasi yang menyatakan bahwa wanita-wanita Indonesia dapat mengalami stress akibat perubahan-perubahan yang terjadi pada diri mereka selama menjalani kehamilan.

Kebutuhan informasi tentang berbagai pengalaman menjalani masa kehamilan di antara wanita Indonesia menjadi sangat penting karena peristiwa motherhood untuk wanita di Indonesia memiliki nilai yang tinggi. Selama masa kehamilan, kebanyakan wanita di Indonesia mengalami berbagai perasaan yang tidak pasti tentang childbirth outcomes berhubungan dengan tingginya angka kematian ibu (AKI) akibat peristiwa kehamilan (Departemen Kesehatan R.I., 1999).

Dalam studi ini peneliti menggunakan berbagai penjelasan yang diungkapkan oleh sejumlah wanita Indonesia yang mengekspresikan berbagai perasaan, pikiran, persepsi, dan pengalaman mereka dalam menjalani masa kehamilan pertama.

\section{BAHAN DAN CARA KERJA}

Studi ini mempelajari pengalaman wanita menjalani masa kehamilan pertamanya dengan menitikberatkan pada arti atau makna menjadi seorang wanita hamil. Fenomena yang mendasarinya adalah perubahan-perubahan fisik dan psikososial yang terjadi selama masa kehamilan. Dengan fokus penelitian kualitatif pada kedalaman dan proses, penelitian ini hanya melibatkan 9 partisipan. Jumlah sample yang relatif kecil pada umumnya digunakan untuk suatu studi kualitatif untuk lebih memberikan perhatian pada kedalaman penghayatan subyek (Morse, 1991; Poerwandari, 1998).

Data studi ini dikumpulkan melalui wawancara formal tidak berstruktur (unstructured formal interviews) yang mendalam sebanyak dua kali dengan para partisipan di rumah masing-masing. Peneliti juga membuat catatan lapangan (field notes) untuk lebih menjamin percapaian hasil deskripsi yang komprehensif dan keakuratan hasil deskripsi tersebut (Streubert \& Carperter, 1999).

Analisis data dilakukan setiap selesai mengumpulkan data dari satu partisipan. Transkriptranskrip dari hasil wawancara dan catatan-catatan lapangan (field notes) yang telah dibuat peneliti secara bersamaan dianalisis dengan teknik analisis spesifik dengan menggunakan pendekatan analisis selektif dan focusing (the selective or highlighting approach) untuk mengungkap dan mengisolasikan berbagai aspek tematik dari fenomena-fenomena yang disoroti dalam studi ini.

\section{HASIL PENELITIAN}

Usia partisipan bervariasi antara 16 tahun sampai 22 tahun. Semua partisipan merupakan penduduk asli desa Warujaya yang memiliki latar belakang pendidikan; 4 orang partisipan telah menyelesaikan studi mereka sampai tingkat sekolah menengah pertama dan 5 orang lainnya hanya menyelesaikan studi mereka pada tingkat sekolah dasar. Semua partisipan dalam kondisi kehamilan sehat, tidak memiliki penyakit penyerta, dan tidak mengalami komplikasi.

\section{GAMBARANBERBAGAIPENGALAMAN PARTISIPAN PADA AWAL 3 BULAN PERTAMAMASA KEHAMILAN}

\section{a). Berbagai ketidaknyamanan fisik dipersepsikan sebagai suatu"penyakit"}

Hasil wawancara menunjukkan bahwa semua partisipan mengalami berbagai ketidaknyamanan fisik, antara lain, mengalami mual dan muntah, cepat merasa lelah, dan mengalami rasa pahit pada mulut. Kondisi ketidaknyamanan tersebut menyebabkan mereka mengalami kesulitan untuk beradaptasi dengan suatu situasi yang secara alami 
terjadi pada awal masa kehamilan. Satu partisipan menuturkan keadaan mual dan muntah yang dialaminya setiap hari selama 2 bulan pertama kehamilannya:

Tidak ada waktu yang pasti tentang keadaan saya mengalami mual dan muntah, tiap hari saya mengalami mual dan muntah yang berbeda-beda munculnya, kadang pagi hari, kadang sore hari. Setiap makan yang berbau bumbu saya muntah, saya merasakan ketidaknyamanan pada diri saya, saya sering bertanya sakit apa saya ini, padahal saya sedang hamil.

Keluhan fisik lainnya, yang dapat terangkum berdasarkan cerita-cerita para partisipan dalam studi ini selama periode trimester pertama kehamilan mereka, bahwa semua partisipan juga mengalami peningkatan frekwensi berkemih. Beberapa orang partisipan mempersepsikan kondisi ini sebagai suatu penyakit yang mereka sebut "beser" dan sebagian lainnya mempersepsikan kondisi mereka yang sering sekali berkemih, dengan istilah penyakit "turun bero".

\section{b). Perasaan ambivalen dan tidak mampu mengontrol emosi.}

Semua partisipan tanpa pengecualian, menjelaskan mereka juga mengalami keluhankeluhan secara psikologis sehubungan dengan kehamilan pertama mereka. Beberapa keluhan secara psikologis yang paling sering dialami oleh kebanyakan partisipan dalam studi ini adalah mereka sering kali mengalami perasaan-perasaan yang saling bertentangan satu sama lainnya (feeling ambivalence). Kebanyakan dari partisipan sering merasa tidak mampu mengontrol perasaan-perasaan tersebut.

Berbagai perasaan yang saling bertentangan dialami para partisipan seringkali timbul akibat harapan-harapan mereka tidak sesuai dengan berbagai kenyataan yang mereka hadapi. Salah seorang partisipan mengungkapkan perasaan mendua yang seringkali dialaminya:
Saya mengalami perasaan yang saling bertentangan dalam diri saya, kadang saya merasa bahagia dengan kehamilan saya ini, tapi seringkali rasa takut yang tidak jelas selalu mengganggu saya, sejumlah pertanyaan sering kali memenuhi pikiran saya yang saya tidak tahu pasti jawabannya.

Perubahan psikologis lainnya yang sering kali juga dialami oleh para partisipan dalam studi ini adalah perasaan tidak dapat mengontrol emosi. Semua partisipan mengekspresikan perasaanperasaan emosi mereka yang seringkali berada dalam level yang tinggi dan sering kali pula mereka tidak dapat mengontrol letupan-letupan emosi mereka. Para partisipan menyakini bahwa mereka memiliki emosi yang labil dan sangat mudah sekali mereka berada dalam situasi marah, mudah tersinggung, dan mudah sekali menangis.

\section{GAMBARAN BERBAGAI PENGALAMAN PARTISIPAN PADA PERIODE 3 BULAN KEDUA MASA KEHAMILAN}

a). Perasaan lebih nyaman dan sejahtera, senang menjadi wanita hamil

Semua partisipan mengekspresikan bahwa ketika kehamilan mereka masuk trimester kedua, pada umumnya mereka merasakan kondisi fisik dan psikologis mereka menjadi lebih baik. Suatu hal yang penting dicatat bahwa memasuki trimester kedua kehamilan mereka, kebanyakan partisipan mengatakan telah terbebas dari berbagai ketidaknyamanan fisik (rasa lelah, mual, muntah, rasa malas, mulut terasa pahit) yang mereka alami pada periode sebelumnya

Saya merasa lebih baik pada saat sekarang ini, rasa cepat lelah yang dulu sempat membuat saya malas beraktivitas, sekarang sudah hilang, saya merasa semangat saya untuk mengerjakan pekerjaan rumah tangga saya bangkit lagi..........yang jelas, keadaan saya menjadi lebih baik dari sebelumnya. 
Semua perempuan dalam studi ini sangat senang dan merencanakan kehamilan mereka. Kesenangan mereka menjadi wanita hamil mereka ceritakan bahwa mereka selalu merawat diri agar selalu sehat dan selalu teratur memeriksakan kehamilan dan kondisi janin mereka kepada bidan mereka.

Sumber kesenangan menjadi wanita hamil adalah ketika para partisipan dapat mendengarkan dan merasakan adanya gerakan-gerakan janin mereka dari dalam perut. Para partisipan dalam studi ini mengekspresikan bahwa mereka menjadi senang dan termotivasi untuk selalu memeriksakan kehamilannya karena dapat mendengarkan suara janin mereka ketika mereka diperiksa oleh bidan mereka.

Betapa senangnya saya, ketika pertama kali diperdengarkan suara bayi saya oleh bidan Eti,.......saat itu saya yakin bahwa bayi saya ada dalam rahim saya....... setiap hari saya juga senang kalau tiba-tiba bayi saya menendang perut saya dari dalam..(partisipan dengan wajah gembira menceritakan kebahagian yang sedang dialaminya).

Selain itu, sehubungan dengan rasa senang mereka menjadi seorang wanita hamil, terjadinya perubahan pada ukuran bentuk tubuh mereka yang semakin hari semakin membesar, akibat semakin tuanya usia kehamilan, semua ibu hamil dalam studi ini menyatakan bahwa diri mereka sudah tidak memiliki bentuk dan ukuran tubuh yang menarik lagi, namun karena rasa senang mereka menjadi wanita hamil, mereka tidak memperdulikannya. Alasan mereka, semua ini demi bayi-bayi mereka.

\section{GAMBARAN BERBAGAI PENGALAMAN PARTISIPAN PADA PERIODE 3 BULAN TERAKHIR MASA KEHAMILAN}

\footnotetext{
a). Kembali merasakan berbagai ketidaknyamanan fisik

Ketidaknyamanan fisik pada bulan-bulan terakhir masa kehamilan mereka kembali diekspresikan oleh para partisipan, antara lain
}

mereka seringkali mengalami kesulitan bernafas ketika mereka dalam keadaan berbaring dengan posisi telentang. Selain itu, rasa terbakar di daerah uluh hati (heartburn) juga mereka alami. Dua dari mereka mengalami bengkak pada daerah ekstremitas bawah dan mereka mengeluh mengalami kesulitan dalam melangkah karena rasa berat ketika melangkahkan kaki mereka. Berikut 2 penuturan yang diekspresikan oleh 2 orang partisipan:

Saya banyak mengalami kesulitan pada bulanbulan terakhir ini, kaki saya menjadi bengkak, menyulitkan saya kalau berjalan, menyebabkan saya harus berjalan lebih lambat. Saya juga mudah sekali merasa lelah dan sering sesak nafas.

Sekarang-sekarang ini, tiap malam, tidur saya terganggu, karena sering terbangun untuk buang air kecil, tidur malam juga saya mengalami kesulitan karena sering sesak nafas kalau lama tidur telentang, jadi serba salah saya saat ini.

b). Perasaan cemas dan takut menghadapi kelahiran bayi.

Salah satu aspek penting akhir dari suatu kehamilan adalah menghadapi kelahiran bayi. Semua partisipan dalam studi ini adalah mereka, para wanita hamil, yang belum memiliki pengalaman sebelumnya melahirkan seorang bayi. Mereka mengatakan tidak memiliki pengetahuan yang cukup untuk mengatasi rasa nyeri saat melahirkan dan belum memiliki pengalaman bagaimana melahirkan bayi dan hal-hal yang berhubungan dengan tanda-tanda akan melahirkan. Beberapa partisipan mengekspresikan tidak dapat membayangkan bagaimana rasanya ketika melahirkan bayi. Semua partisipan dalam studi ini mengalami perasaan cemas dan takut menghadapi kelahiran bayi mereka. Salah satu di antara mereka menjelaskan tentang perasaan cemas dan takutnya:

Yang menjadi pikiran saya saat ini, saya belum bisa membayangkan bagaimana saya nanti 
melahirkan bayi saya, kata orang-orang yang sudah pernah melahirkan, katanya nanti akan mules dan sakit saat melahirkan. .....saya masih terus membayangkan bagaimana nanti saya bisa mengatasi nyeri saat melahirkan bayi saya nanti.....

Belum memiliki pengalaman melahirkan menyebabkan para partisipan memiliki rasa takut untuk memutuskan hal-hal terbaik yang dapat dilakukannya untuk mempersiapkan kelahiran bayi mereka. Kebanyakan dari partisipan, mengikuti berbagai tradisi, praktek-praktek budaya dan nasihat-nasihat dari para orang tua mereka, seperti anjuran memantang makanan tertentu, misalnya tidak diperbolehkan makan ikan dan sayuran tertentu, anjuran memakan telur ayam mentah yang dicampur dengan satu sendok minyak sayur setiap pagi, anjuran untuk selalu melakukan aktivitas menimba air dari sumur, dan anjuran serta nasihat lainnya dari para orang-orang tua mereka, pada umumnya mereka patuhi dan mereka lakukan.

\section{c). Seorang wanita membutuhkan bantuan dan dukungan ketika ketika dirinya hamil untuk pertama kali.}

Kebutuhan bantuan dan dukungan sangat jelas diperlukan oleh semua partisipan dalam studi ini. Karena belum memiliki pengalaman dan pengetahuan sebelumnya dalam mengatasi berbagai ketidaknyamanan fisik dan keluhankeluhan yang dapat mereka alami, para partisipan dalam studi ini memerlukan berbagai bantuan dan dukungan baik berupa pengetahuan untuk mengatasi berbagai ketidaknyamanan fisik dan psikologis yang dapat dialami selama masa hamil atau bantuan nyata untuk mengurangi beban berat sehari-hari dari pekerjaan mereka. Bantuan dan dukungan yang dimaksud dapat diperoleh baik dari para praktisi kesehatan atau pun dari para kaum keluarga dekat mereka. Semua partisipan dalam studi ini mengatakan bahwa mereka banyak mendapat bantuan dan perhatian dari para suami, orang tua, dan anggota keluarga dekat mereka lainnya. Berikut pernyataan dari salah seorang partisipan:

Selama hamil ini, saya merasa banyak keluarga saya memperhatikan kebutuhan saya, saya merasa sangat special, semua orang di rumah saya membantu saya.

Selain mendapat perhatian dan dukungan dari para suami mereka, mereka juga merasakan adanya perubahan hubungan, yaitu hubungan mereka menjadi lebih baik dan harmonis dengan para suami dan anggota keluarga mereka.

Berkaitan dengan bantuan yang diterima dari para praktisi kesehatan, dalam hal ini bidan yang membantu memeriksa kehamilan mereka, secara umum, para partisipan menceritakan ketika memeriksakan kehamilan, mereka hanya menerima pemeriksaan fisik dan obat atau vitamin untuk ibu hamil yang mereka perlukan dan sangat kurang menerima informasi dan penjelasanpenjelasan yang membekali mereka mengatasi berbagai ketidaknyamanan fisik yang mereka alami dan tentang persiapan-persiapan yang mereka perlukan untuk menghadapi persalinan dan merawat diri dan bayi mereka setelah melahirkan kelak.

Semua ibu hamil dalam studi ini mengekspresikan harapan mereka, yaitu, para bidan dapat memberikan dukungan dan bantuan kepada mereka tidak hanya berupa pemeriksaan fisik saja, tapi memberikan pula informasi dan pengetahuan tentang kehamilan dan persalinan yang mereka sangat butuhkan ketika mereka datang untuk periksa hamil. Ekspresi salah satu partisipan, sebagai berikut:

Kalau saya datang periksa hamil, ibu bidan hanya memeriksa perut saya, menimbang berat badan saya, dan mengukur tensi saya. Dia tidak pernah diskusi dengan saya tentang kehamilan saya, bagaimana anak saya di dalam, padahal saya ingin dia cerita dan memberi penjelasan tentang merawat anak, bagaimana supaya saya 
dapat melahirkan dengan lancar, dan banyak deh...saya saya butuhkan, tapi itu tidak pernah saya dapat dari ibu bidan.........

\section{DISKUSI}

Berbagai ketidaknyamanan fisik dan ketidakmampuan dalam melakukan pengontrolan emosi merupakan tema-tema utama yang menggambarkan pengalaman-pengalaman para ibu hamil dalam studi ini ketika mereka menjalani kehamilan pertama mereka. Tema-tema tersebut mengidentifikasi terdapatnya suatu tantangan besar yang dialami oleh seorang wanita hamil berhubungan dengan terjadinya perubahan-perubahan fisiologis dan psikologis yang secara alami terjadi akibat suatu kehamilan. Sebagai contoh, berhubungan dengan ketidaknyamanan psikogis, dalam hal ini terjadinya ketidakmampuan wanita hamil dalam mengontrol situasi emosi mereka saat selama kehamilan, yang dialami oleh para partisipan dalam studi ini, juga dialami oleh para partisipan dalam studi yang dilakukan oleh Mackey (1990). Mackey dalam studinya tersebut melaporkan bahwa lebih dari $60 \%$ wanita hamil mengalami perilaku yang tidak adekuat, seperti mudah marah, mudah tersinggung, dan mudah menangis karena ketidakmampuan mereka mengontrol emosi selama masa kehamilan.

Semua ibu hamil, tidak terkecuali para partisipan dalam studi ini melaporkan adanya perubahanperubahan kehidupan yang terjadi pada mereka selama menjalani masa kehamilan. Salah satu di antaranya adalah adanya perubahan hubungan mereka dengan para suami dan anggota keluarga mereka lainnya sejak kehamilan mereka. Laporan-laporan seperti ini menjadi sangat umum ditemukan pada studistudi terdahulu tentang berbagai pengalaman wanita seputar kehamilan dan melahirkan (Stoppart, 1996; LeBlanc, 1999). Tidak terkecuali, studi selanjutnya yang dilakukan oleh Schneider (2002) yang meneliti pengalaman 13 orang wanita Australia dengan kehamilan pertama mereka dengan berbagai pengalaman mereka mengalami perubahan hubungan dengan suami dan keluarga mereka.
Laporan lainnya dari 13 partisipan dari penelitian yang dilakukan oleh Schneider (2002) menceritakan pula bahwa mereka sangat membutuhkan dukungan dari keluarga dan suami selama periode kehamilan mereka dan tidak terkecuali hal yang sama juga dilaporkan oleh para ibu hamil dalam studi ini. Seperti yang diceritakan para ibu hamil dalam studi ini, terdapat suatu penjelasan yang mengindikasikan bahwa para ibu hamil membutuhkan bantuan dan dukungan ketika mereka menjalani kehamilan pertama mereka dan satu tema yang dirumuskan dari hasil analisis tematik studi ini, yaitu, "Seorang wanita membutuhkan bantuan dan dukungan ketika dirinya menjalani kehamilan untuk pertama kali", telah memberi penjelasan bahwa para wanita yang pertama kali hamil sangat membutuhkan bantuan dan dukungan baik dari keluarga mereka maupun dari para praktisi kesehatan.

Hal lain yang perlu didiskusikan dalam pembahasan ini, yaitu berhubungan dengan kebutuhan dan harapan mendapatkan berbagai informasi yang diperlukan para wanita hamil dari para praktisi kesehatan adalah semua partisipan dalam studi ini sangat membutuhkan dukungan dalam hal penerimaan informasi tentang seputar kehamilan dan kelahiran dari para praktisi kesehatan yang pada kenyataannya tidak mereka dapatkan. Hasil temuan ini paralel dengan harapan-harapan para ibu hamil dari Finland ketika mereka mengekspresikan berbagai harapan dan keinginan untuk mendapatkan informasi-informasi yang mereka perlukan setiap kali melakukan kunjungan pemeriksaan kehamilan mereka di pusat-pusat klinik maternitas di Finland (Bondas, 2002).

\section{KESIMPULAN}

Beradaptasi dengan peristiwa kehamilan bukan merupakan suatu kemampuan yang secara otomatis dapat dilakukan oleh semua wanita hamil. Untuk dapat beradaptasi dan mendapatkan pengalaman yang menyenangkan ketika menjalani masa kehamilan, para wanita hamil, khususnya bagi mereka yang baru pertama kali mengalami 
kehamilan, sangat membutuhkan berbagai dukungan dan bantuan (informasi, bantuan dalam meringankan pekerjaan fisik sehari-hari) baik dari keluarga mereka sendiri maupun dari para praktisi kesehatan yang ada di lingkungan mereka.

Studi ini memberikan wawasan, informasi, dan pemahaman tentang pengalaman-pengalaman wanita menjalani masa kehamilan pertama mereka yang pada gilirannya memberikan pemahaman yang lebih luas dan dalam bagi perawat maternitas dan petugas kesehatan lainnya tentang apa yang terjadi terhadap wanita pada periode tersebut dan bagaimana persepsi wanita tentang dirinya ketika menjalani masa kehamilannya. (MS).

* Yati Afiyanti, SKp., MN: Staf Akademik Kelompok Keilmuan Maternitas dan Anak Fakultas Ilmu Keperawatan UI

\section{KEPUSTAKAAN}

Ball, J.A. (1994). Reactions to motherhood: The role of post-natal care. New York: Cambrige University Press.

Barclay, L., Everitt, L., Rogan, F., Schmied, V., \& Wyllie, A. (1997). Becoming a mother-an analysis of women's experience of early motherhood. Journal of Advanced Nursing, 25, 719-728.

Departement Kesehatan R.I. (1999). Profil Kesehatan Indonesia 1999. Jakarta: Pusat Data Kesehatan.

LeBlanc W. (1999). Naked motherhood. Australia: Random House.

Morse, J. (Ed.). (1991). Qualitative health research. Newbury Park, CA: Sage.

Poerwandari, E. K. (1998). Pendekatan kualitatif dalam penelitian psikologi. Jakarta: LPSP3, Fakultas Psikologi Universitas Indonesia.

Richardson, D. (1993). Women, motherhood and childrearing. New York: St. Martin's Press.

Schneider, Z. (2002). An Australian study of women's experiences of their first pregnancy. Midwifery, 18, 238-249.

Stoppard M. (1996). Newpregnancy and birth book. Hongkong: Wing King Tong.

Streubert, H.J., \& Carpenter, D.R. (1999). Qualitative research in nursing: Advancing the humanistic imperative (2nd ed.). Philadelphia, PA: Lippincott. 


\section{Lampiran A}

\section{Data Demografi}

1. Nama Ibu:

2. Usia:

3. Status perkawinan:

4. Pendidikan terakhir:

5. Komplikasi selama hamil (jika ada):

6. Usia kehamilan saat wawancara pertama (minggu):

7. Periksa hamil oleh:

Orang yang tinggal dengan ibu saat ini: (sebutkan semua yang tinggal bersama ibu)
Lampiran B

\section{Pedoman Wawancara:}

1. Bagaimana pengalaman ibu menjalani kehamilan saat ini?

- Bagaimana ibu melihat diri sendiri saat ini?

- Bagaimana perubahan-perubahan yang terjadi yang ibu alami selama kehamilan ini (perubahan fisik, perubahan sosial, perubahan hubungan dengan suami, atau orang tua atau mertua, atau dengan teman)

- Tantangan atau masalah apa saja yang paling ibu alami saat selama hamil

- Kebahagiaan yang seperti apa yang ibu alami dan rasakan selama hamil

- Bagaimana ibu merawat diri selama hamil

- Siapa yang membantu ibu selama ini (kemana ibu biasa bertanya; kepada siapa ibu biasanya cerita tentang masalahmasalah yang ibu alami selama hamil)

- Bagaimana pengalaman ibu dengan petugas kesehatan yang memeriksa kehamilan ibu

2. Pengalaman lainnya yang ingin ibu ceritakan? 